\title{
Gestational age-dependent changes in the levels of mRNAs encoding cortisol biosynthetic enzymes and IGF-II in the adrenal gland of fetal sheep during prolonged hypoxemia
}

\author{
G A Braems ${ }^{1,3}$, V K M Han ${ }^{2,3,4}$ and J R G Challis ${ }^{1,3,4}$ \\ ${ }^{1}$ Department of Physiology, Faculty of Medicine, University of Toronto, Toronto, Ontario, Canada, ${ }^{2}$ Departments of Pediatrics, Obstetrics and Gynecology, \\ Anatomy and Cell Biology, and Biochemistry, University of Western Ontario, London, Ontario, Canada, ${ }^{3}$ The Lawson Research Institute, \\ St Joseph's Health Center, London, Ontario, Canada and ${ }^{4} \mathrm{MRC}$ Group in Fetal and Neonatal Health and Development \\ (Requests for offprints should be addressed to J R G Challis, Department of Physiology, Faculty of Medicine, 1 King's College Circle, Room 3205/7, \\ University of Toronto, Toronto, Ontario, Canada M5S 1A8) \\ (G A Braems is now at Department of Obstetrics and Gynecology, University Hospital, Klinikstr. 32, D-35385, Giessen, Germany)
}

\begin{abstract}
Hypoxemia represents a major stress for the fetus, and is associated with alterations and adaptations in cardiovascular, metabolic and endocrine responses, which in turn may affect tissue growth and differentiation. To determine the effects of hypoxemia on fetal adrenal activity and growth, we subjected sheep fetuses at days 126-130 and 134-136 (term 145 days) to reduced $\mathrm{PaO}_{2}$ by reducing the maternal fraction of oxygen for $48 \mathrm{~h}$ (mean reduction of $6.8 \mathrm{mmHg}$ ), without change in arterial $\mathrm{pH}$ or $\mathrm{PaCO}_{2}$. This stimulus resulted in similar increases in the plasma immunoreactive ACTH response at both ages. Among adrenal steroids, plasma cortisol $\left(\mathrm{C} 21 \Delta_{4}\right)$ rose in both groups of animals, but plasma androstenedione $\left(\mathrm{C}_{19 \Delta_{4}}\right)$ declined marginally, resulting in a pronounced increase in the cortisol:androstenedione ratio in the plasma that was greater and more sustained in the older fetuses. In the younger fetuses, after $48 \mathrm{~h}$ of hypoxemia, there were no significant changes in
\end{abstract}

mRNAs encoding steroidogenic enzymes in the fetal adrenal gland. However, in the older fetuses, hypoxemia resulted in significantly increased levels of mRNAs encoding $\mathrm{P} 450_{\mathrm{scc}}, \mathrm{P} 450_{\mathrm{C} 21}$ and $3 \beta$-hydroxysteroid dehydrogenase, but not for $\mathrm{P}_{45} 0_{\mathrm{C} 17}$, in the fetal adrenal gland. Levels of IGF-II mRNA in the fetal adrenal gland fell in both groups of fetuses, and this response was greater at the later gestational age. We conclude that sustained hypoxemia is a potent stimulus which activates adrenal steroidogenesis in the late gestation fetal sheep. The resultant increase in cortisol synthesis is associated with decreased expression of adrenal IGF-II mRNA. We speculate that this relationship might influence patterns of fetal organ growth and differentiative function in response to fetal stress such as hypoxemia.

Journal of Endocrinology (1998) 159, 257-264

\section{Introduction}

Hypoxemia is a potent stimulus which increases the activity of the hypothalamic-pituitary-adrenal (HPA) axis in the fetus. In response to short-term $(60 \mathrm{~min})$ hypoxemia, there are increases in fetal plasma concentrations of adrenocorticotrophin (ACTH), vasopressin and cortisol (Boddy et al. 1974, Rurak 1978, Stark et al. 1982, Akagi \& Challis 1990). The magnitude of these changes varies at different gestational ages in relation to the progressive maturation of fetal HPA function. Thus, later in gestation, the plasma cortisol response to acute hypoxemia is enhanced, and the ACTH response diminished, presumably as a result of increased fetal adrenal responsiveness, and greater negative feedback by the elevated basal and stimulated glucocorticoid concentrations (Norman et al. 1985, Akagi \& Challis 1990). However, there is no information available concerning the effects of hypoxemia on levels of expression of key enzymes in the biosynthetic pathway of fetal adrenal glucocorticoids that might underlie these changes in plasma hormone concentrations.

We have recently developed a model of prolonged $(48 \mathrm{~h})$ fetal hypoxemia without concurrent changes in fetal $\mathrm{PaCO}_{2}$ or $\mathrm{pH}$, to examine effects on fetal HPA function (Braems et al. 1996). To identify the gestational agedependent changes, fetuses were studied on two occasions in late gestation, before and after day 130 of pregnancy (term 145 days), since this is a period of rapid change in HPA responsiveness. Hypoxemia produced similar changes in plasma immunoreactive (ir) ACTH in both groups of animals, but the change in plasma cortisol was greater and more sustained in the older fetuses. The objective of the present study was to determine whether the alteration of fetal adrenal function extended to C19 steroids, and whether age-dependent differences in 
fetal adrenal responses were related to differences in the levels of mRNAs encoding key steroidogenic enzymes. We also measured levels of plasma androstenedione, which contributes about 30\% of the precursor for fetoplacental estrogen production in sheep during late pregnancy (Mitchell et al. 1986). In the sheep fetal adrenal, androstenedione appears to be analogous to dehydroepiandrosterone (DHEA) sulfate from the human fetal adrenal as the precursor for placental estrogen biosynthesis (Albrecht \& Pepe 1990).

The increased output of cortisol in the late gestation fetal sheep contributes to fetal organ maturation and to the onset of parturition (Liggins 1994, Matthews \& Challis 1996). Fetal hypercortisolemia may also lead to fetal growth restriction. Exogenous glucocorticoids decrease $\left[{ }^{3} \mathrm{H}\right]$ thymidine incorporation into several fetal tissues, including the brain (Reinisch et al. 1978), and reduce insulin-like growth factor-II (IGF-II) expression in many fetal organs (Li et al. 1993). We have reported previously that IGF-II mRNA is abundantly expressed in the steroidogenic cells of the ovine fetal adrenal (Han et al. 1992) and IGF-II mRNA levels in the adrenal cortex are reduced in fetal sheep infused with either ACTH or cortisol at various times during the last third of pregnancy (Lu et al. 1994). Therefore, a further aim of the present study was to determine whether the elevation of cortisol produced in response to hypoxemia was associated with altered expression of the IGF-II gene in the fetal adrenal glands.

\section{Materials and Methods}

\section{Animals and surgery}

Details of the animals used in these experiments have been described elsewhere (Braems et al. 1996). Animal protocols were approved by the Animal Care Committees of the Lawson Research Institute and of the University of Western Ontario, according to the guidelines of the Canadian Council on Animal Care. Briefly, vascular catheters were implanted into two groups of fetal sheep at either days 118-122 $(n=18)$ or days 126-128 $(n=10)$ of gestation. Experiments were performed in the younger group of animals beginning on days 124-128, and in the older animals beginning on days 132-134 of pregnancy. Fetal hypoxemia was produced by the mother breathing a gas mixture containing a lowered fraction of oxygen, and was continued for $48 \mathrm{~h}$. Control animals continued to breath room air. Fetal hypoxemia was produced in eight fetuses in the younger age group, and in five in the older age group; there were ten and five normoxemic fetuses respectively at the two ages. Blood samples were collected from a fetal artery $(2.5 \mathrm{ml})$ and a maternal artery $(5.0 \mathrm{ml})$ into chilled heparinized syringes at $8 \mathrm{~h}$ intervals before and during the period of hypoxemia, for measurement of blood gases with a blood gas analyzer (Radiometer, Copenhagen,
Denmark), plasma ir-ACTH and cortisol (Braems et al. 1996) and androstenedione (Mitchell et al. 1986) by RIA. The mean intra- and interassay coefficients of variation for the androstenedione assay were 5.3 and $9.0 \%$ respectively.

At the end of the experimental period (days 126-130 and days 134-136) the animals were killed by maternal i.v. injection of pentobarbital sodium (Euthanol, Abbott Laboratories, Montreal, Canada). The fetuses were delivered immediately by hysterotomy, and fetal tissues including the adrenal glands were removed, frozen using liquid nitrogen, and stored at $-80{ }^{\circ} \mathrm{C}$ for later analysis. Levels and distribution of proopiomelanocortin (POMC) mRNA in the fetal pituitary were determined by in situ hybridization and have been reported elsewhere (Braems et al. 1996).

\section{Northern blot analysis}

Total RNA was extracted using the lithium chloride-urea method (Auffray \& Rougeon 1980). The integrity of the RNA was assessed after electrophoresis on a $1 \%(\mathrm{w} / \mathrm{v})$ agarose gel, and stained with ethidium bromide. Only the RNA samples without evidence of degradation were used. Electrophoresis of RNA $(20 \mu \mathrm{g})$ samples was performed as described (Berdusco et al. 1993) on 1\% agarose (w/v), $2 \cdot 2 \mathrm{M}$ formaldehyde gels, and was followed by capillary transfer to a nylon membrane (Zetaprobe, Bio-Rad, Mississauga, Ontario, Canada). The RNA was covalently cross-linked to the membrane by UV light (GS Gene Linker, Bio-Rad, Hercules, CA, USA). The membrane was prehybridized at $42{ }^{\circ} \mathrm{C}$ overnight in a buffer containing $50 \%(\mathrm{v} / \mathrm{v})$ formamide, $7 \%(\mathrm{w} / \mathrm{v})$ SDS, $4 \times \operatorname{SSPE}(35 \mathrm{~g}$ $\mathrm{NaCl}, 5 \cdot 5 \mathrm{~g} \mathrm{NaH}_{2} \mathrm{PO}_{4}$ and $1.5 \mathrm{~g}$ EDTA per liter, $\mathrm{pH} 7 \cdot 4$ ) and $0.5 \mathrm{mg} / \mathrm{ml}$ denatured salmon sperm.

The membranes were then hybridized overnight with one of the following oligonucleotide probes encoding steroidogenic enzymes, or an ovine IGF-II cDNA (Han et al. 1992). The difference in loading and transfer among different lanes was assessed by hybridizing the blots with a cDNA encoding mouse $18 \mathrm{~S}$ ribosomal RNA. The 45-mer oligonucleotide probes were synthesized based on the DNA sequences for ovine $\mathrm{P} 450_{\mathrm{C} 21}$ (Crawford et al. 1992), $\mathrm{P}^{4} 40_{\mathrm{C} 17}$ and $\mathrm{P} 450_{\mathrm{scc}}$ (Tangalakis et al. 1990) and human $3 \beta$-hydroxysteroid dehydrogenase (3ß-HSD) type II (Lorrence et al. 1990) mRNAs as recorded in the DNA database of the European Molecular Biology Laboratory (EMBL) Gene Bank (Heidelberg, Germany). The probes were prepared by solid phase synthesis using a Beckman Oligo 1000 DNA Synthesizer (Fullerton, CA, USA) and were purified on an $8 \%$ polyacrylamide/8 $\mathrm{M}$ urea sequencing gel. Probes were complementary to the mRNAs encoding HSD-II (bases 794-838) for 3 $\beta-H S D$, and SHPCYTOC (bases 1496-1540) for $\mathrm{P} 450_{\mathrm{C} 21}$. The oligonucleotide for $\mathrm{P} 450_{\mathrm{C} 17}$ (Tangalakis et al. 1990) was extended with GA at the $5^{\prime}$ end and GCT GCC CAT CAT $\mathrm{C}$ at the $3^{\prime}$ end, and the oligonucleotide for $\mathrm{P}^{4} 50_{\text {scc }}$ 
was elongated by CCAG at the $5^{\prime}$ end and AACTT at the $3^{\prime}$ end. The probes were $5^{\prime}$-end labeled (Sambrook et al. 1989) with $\left[\gamma^{32} \mathrm{P}\right]$ ATP (specific activity $3000 \mathrm{Ci} / \mathrm{mmol}$; DuPont NEN, Mississauga, Ontario, Canada) using T4 polynucleotide kinase (Promega, Madison, WI, USA). The ovine IGF-II cDNA was labeled with $\left[{ }^{32} \mathrm{P}\right] \mathrm{dCTP}$ using random priming as described (Han et al. 1992). Probes were added $\left(1 \cdot 0-1.5 \times 10^{6}\right.$ c.p.m. $/ \mathrm{ml}$ buffer $)$ to the membranes, hybridized overnight, and then washed at the highest stringency of $0.1 \times \mathrm{SSC}$ at $50{ }^{\circ} \mathrm{C}$. Blots were exposed to X-ray film (XAR, Kodak Laboratories, Rochester, NY, USA) within the linear range of the film and the relative optical densities were determined by computerized image analysis (Imaging Research Inc., St Catherines, Ontario, Canada). Blots were stripped by boiling, and checked by autoradiography before being reprobed. Negative controls for the oligonucleotide probes included Northern blots of fetal sheep liver total RNA, which showed no hybridization when processed identically to the adrenal blots (data not shown).

\section{Data analysis}

Results are expressed as means \pm s.E.M. Group comparison was performed by one-way and two-way ANOVA. Corrections were made for repeated measures, and if significance was obtained $(P<0 \cdot 05)$ these were followed by Duncan's multiple range test or specified contrasts with Student's $t$-test.

\section{Results}

Blood gases and plasma ir-ACTH

We have described previously in detail the changes in blood gases, plasma ir-ACTH and levels of pituitary POMC mRNA in these animals (Braems et al. 1996). Briefly, fetal $\mathrm{PaO}_{2}$ values were similar $(20 \mathrm{mmHg})$ at the start of the experiment in all groups of fetuses. During hypoxemia fetal $\mathrm{PaO}_{2}$ fell by $6.9 \pm 1.1 \mathrm{mmHg}$ in the younger fetuses, and by $6 \cdot 8 \pm 1 \cdot 1 \mathrm{mmHg}$ in the older fetuses. There were no significant effects of hypoxemia on fetal arterial $\mathrm{PaCO}_{2}$ or $\mathrm{pH}$.

Concentrations of ir-ACTH rose significantly within $2 \mathrm{~h}$ of the beginning of hypoxemia at both gestational ages, and then decreased by $18 \mathrm{~h}$ to mean values that were higher than those in controls, but they were not different statistically. There was no significant difference in the peak ir-ACTH values, nor in the integrated ACTH response (area under the curve) between the younger and older fetuses (Braems et al. 1996).

\section{Plasma cortisol and androstenedione concentrations}

The mean plasma cortisol concentrations were $3 \cdot 1 \pm$ $0.3 \mathrm{ng} / \mathrm{ml}$ and $8 \cdot 9 \pm 1 \cdot 1 \mathrm{ng} / \mathrm{ml}$ in the younger and older fetuses respectively during the period before hypoxemia.
During hypoxemia, plasma cortisol concentrations rose to maximum values of $10 \mathrm{ng} / \mathrm{ml}$ in the younger fetuses and $30 \mathrm{ng} / \mathrm{ml}$ in the older animals. In the fetuses at days 134-136 of gestation, the elevation in plasma cortisol was sustained over the $48 \mathrm{~h}$ experimental period. Mean androstenedione concentrations were similar (550$600 \mathrm{pg} / \mathrm{ml}$ ) at the start of the experiment in all groups of animals (Fig. 1, upper panels). During hypoxemia, there was a gradual decline in androstenedione concentrations such that during the second $24 \mathrm{~h}$ period, the mean values of androstenedione had decreased by 15 and $18 \%$ for the younger and older fetuses respectively, compared with the $24 \mathrm{~h}$ before starting hypoxemia in these animals (both $P<0 \cdot 05$; Fig. 1). The different patterns of change in plasma cortisol and androstenedione resulted in a significant increase in the ratio of cortisol:androstenedione concentrations in plasma, which was greater and more sustained in the older animals (Fig. 1, lower panels).

\section{Adrenal steroidogenic enzyme $m R N A$ expression}

Northern blotting identified single transcripts for $\mathrm{P}_{450} \mathrm{scc}_{\mathrm{sc}}$ (size $1.9 \mathrm{~kb}$ ), $\mathrm{P} 40_{\mathrm{C} 17}$ (size $1.7 \mathrm{~kb}$ ) and $3 \beta-\mathrm{HSD}$ (size $2 \cdot 0 \mathrm{~kb})$, and two major transcripts for $\mathrm{P}^{4} 50_{\mathrm{C} 21}(1.7 \mathrm{~kb}$ and $2.2 \mathrm{~kb}$ ) in adrenal tissue from all groups of fetuses. There were no significant differences in the levels of mRNAs encoding $\mathrm{P} 450_{\mathrm{scc}}, \mathrm{P} 450_{\mathrm{C} 17}, \mathrm{P} 450_{\mathrm{C} 21}$ or $3 \beta-\mathrm{HSD}$ in adrenal tissue from normoxemic fetuses at the two gestational ages (Fig. 2). However, there was a dramatic difference between the younger and older fetuses in the effect of hypoxemia on levels of mRNA for key steroidogenic enzymes in the fetal adrenal gland (Fig. 2). Hypoxemia had no significant effect on the mRNA levels of any of the four steroidogenic enzymes in the adrenal tissue from the younger fetuses (Fig. 2). In contrast, in the older group of fetuses there were significant increases in the levels of mRNAs encoding $\mathrm{P}_{450} \mathrm{scc}_{\mathrm{sc}}(P<0.001), \mathrm{P}^{2} 50_{\mathrm{C} 21} 1.7 \mathrm{~kb}$ transcript $(P<0 \cdot 05)$, and for $3 \beta-H S D(P<0 \cdot 05)$, but not for $\mathrm{P}_{450} 0_{\mathrm{C} 17}$ or $\mathrm{P} 450_{\mathrm{C} 21} 2 \cdot 2 \mathrm{~kb}$ transcript (Fig. 2).

\section{Adrenal IGF-II $m R N A$}

Seven IGF-II mRNA transcripts $(7 \cdot 2 \mathrm{~kb}$ to $0 \cdot 8 \mathrm{~kb})$ were identified in the adrenal glands of normoxic and hypoxic fetuses from both gestational age groups. The mean levels of total IGF-II mRNA in adrenal tissue from normoxemic fetuses at the two gestational ages were not statistically different. After $48 \mathrm{~h}$ hypoxemia there was a decrease in the levels of total IGF-II mRNA in adrenal tissues from both groups of animals, and this was statistically significant in the older fetuses (Fig. 3).

\section{Discussion}

We have reported previously that in response to sustained hypoxemia for $48 \mathrm{~h}$, the concentration of cortisol in the plasma of fetal sheep rises, and this response is greater and 


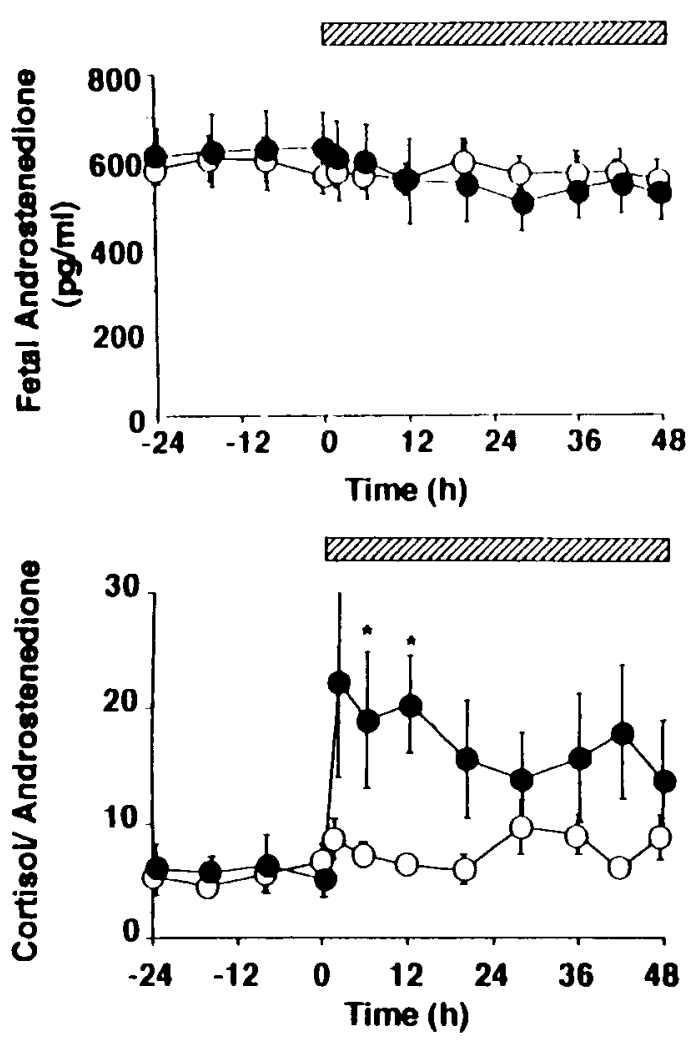

d 126-130
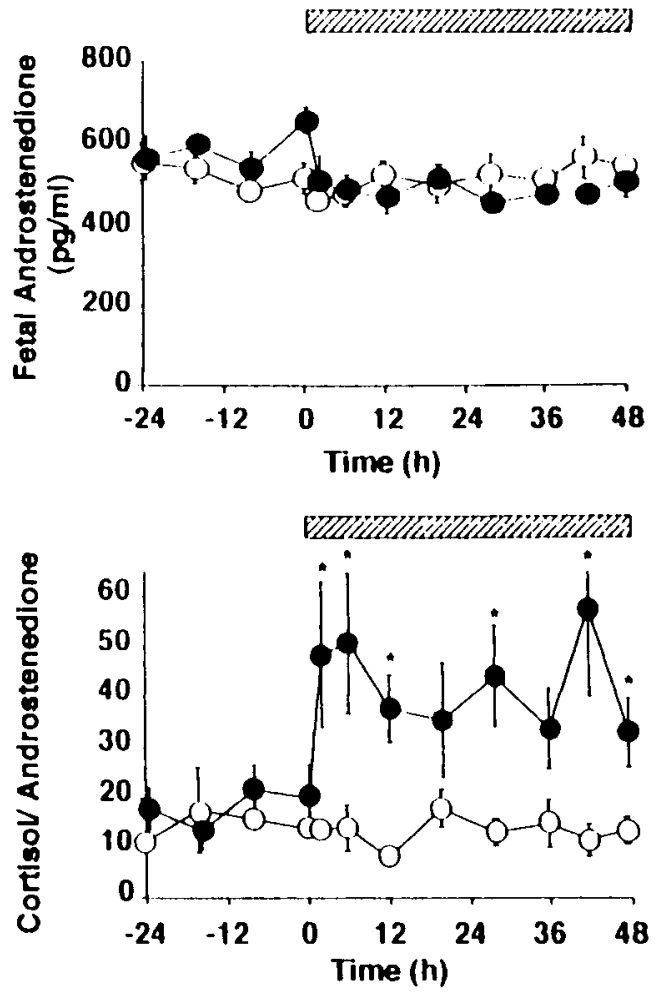

d 134-136

Figure 1 Concentrations of androstenedione (upper panels) and the ratio of plasma cortisol:androstenedione (lower panels) in the plasma of fetal sheep at days 126-130 and 134-136 of gestation. Animals were made hypoxemic (solid symbols) or remained normoxemic (open symbols) for $48 \mathrm{~h}$ after an initial $24 \mathrm{~h}(-24$ to $0 \mathrm{~h}$ ) control period. The experimental period (hatched horizontal bars) was between 0 and 48 h. Values are means \pm S.E.M. ${ }^{*} P<0.05$ between hypoxemic and normoxemic fetuses.

more sustained in fetuses at days 134-136 of gestation compared with those 6-10 days earlier in gestation (Braems et al. 1996). This is because adrenal steroidogenesis is directed towards cortisol at the later gestational age. We now report that plasma androstenedione concentrations are relatively unchanged, or even decline gradually over this same period of time. This results in an increase in the plasma cortisol:androstenedione ratio. The sustained nature of these changes in plasma hormone concentrations is consistent with increases in mRNAs encoding $\mathrm{P} 450_{\mathrm{scc}}$, $3 \beta-\mathrm{HSD}$ and $\mathrm{P}_{450} \mathrm{C} 21_{1}$ in adrenal tissue from the older fetuses. In both groups of animals there was a concomitant fall in IGF-II mRNA levels in the fetal adrenal gland with a more pronounced change within older fetuses suggesting a relationship between IGF-II gene expression and corticosteroid biosynthesis.

We have shown previously that after hypoxemia, the increases in ir-ACTH in plasma and POMC mRNA in the fetal pars distalis were similar in both groups of animals (Braems et al. 1996). Levels of POMC mRNA in the pars intermedia fell, however, indicating a differential regulation of POMC gene expression in different regions of the pituitary (Braems et al. 1996). It remains to be established whether there are changes in the pattern of larger molecular weight ACTH-related peptides in plasma after hypoxemia that could affect the different patterns of adrenal steroidogenic enzymes in the two groups of animals. The ovine fetal adrenal does not have the same relative deficiency of $3 \beta-H S D$ (Riley et al. 1992, Phillips et al. 1996) as the fetal zone of the primate fetal adrenal (Seron-Ferre et al. 1978, Pepe \& Albrecht 1990, Mason et al. 1993) and androstenedione appears to be a reasonable indicator of C19 steroid secretion. Earlier studies showed that the mRNA levels for steroidogenic enzymes in the fetal adrenal reflected changes in enzyme bioactivities (Tangalakis et al. 1989). Thus, increases in $\mathrm{P} 450_{\mathrm{scc}}$, $3 \beta-\mathrm{HSD}$ and $\mathrm{P} 450_{\mathrm{C} 21}$ may favor steroidogenesis along the $\mathrm{C} 21 \Delta_{4}$ pathway, although we recognize that $\mathrm{P}^{4} 50_{\mathrm{C} 17}$, which is required for cortisol biosynthesis, did not change significantly in the present experiments. 

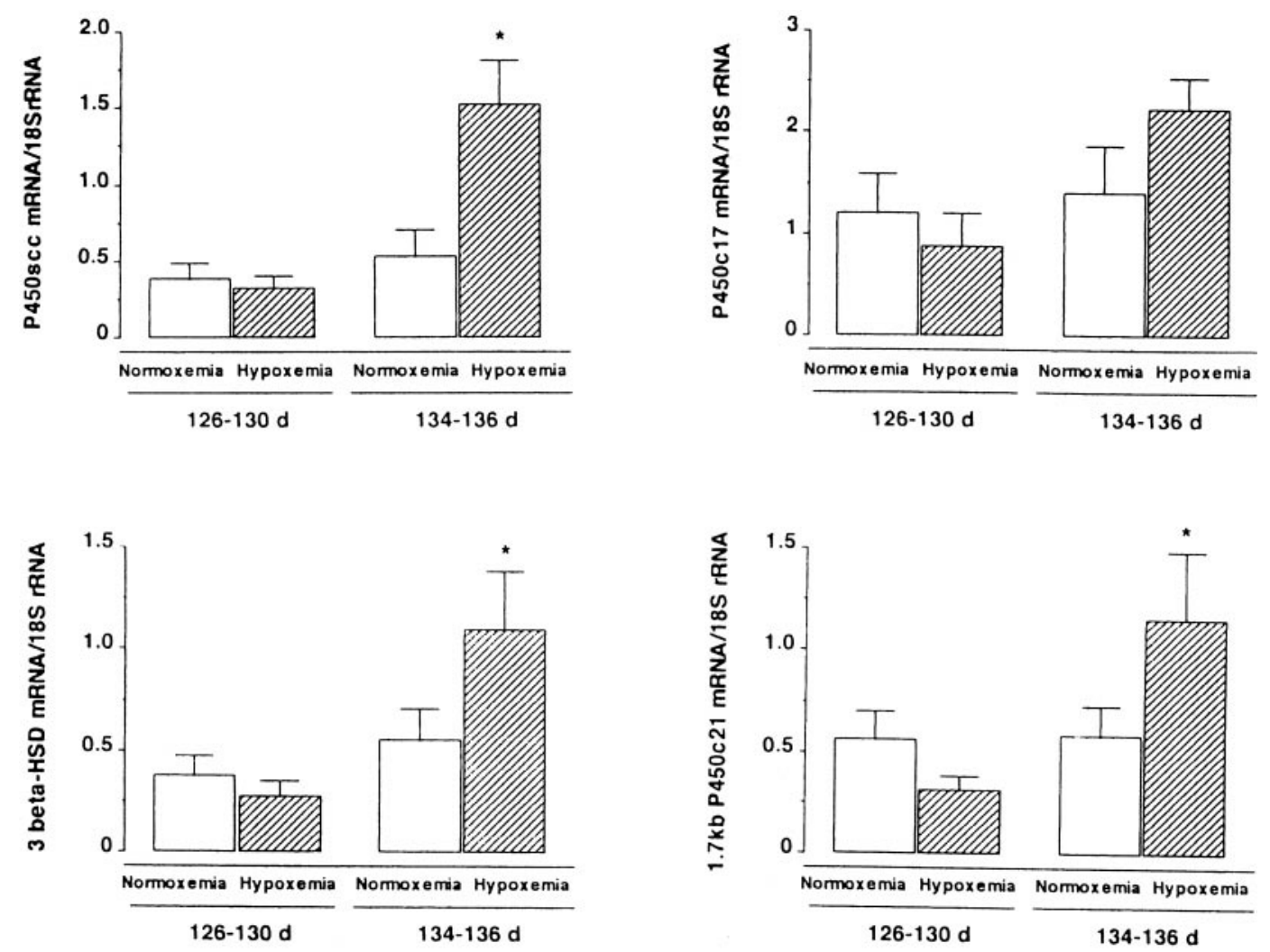

Figure 2 Ratio of mRNA encoding $\mathrm{P} 450_{\mathrm{scc}}, \mathrm{P} 450_{\mathrm{C} 17}, 3 \beta-\mathrm{HSD}$, and the $1.7 \mathrm{~kb} \mathrm{P} 450_{\mathrm{C} 21}$ to $18 \mathrm{~S}$ rRNA in adrenal tissue collected from fetal sheep after $48 \mathrm{~h}$. exposure to normoxemia (open bars) or hypoxemia (hatched bars) at 126-130 and 134-136 days of gestation. Values are mean \pm S.E.M. ${ }^{*} P<0 \cdot 05$.

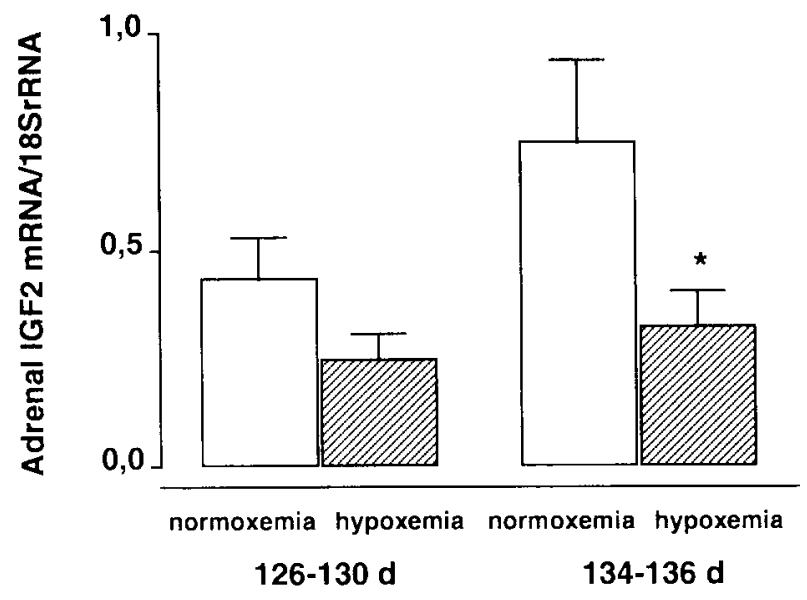

Figure 3 Levels of mRNA encoding IGF-II (ratio IGF-II mRNA/18S rRNA) in adrenal tissue from fetal sheep exposed for $48 \mathrm{~h}$ to normoxemia (open bars) or hypoxemia (hatched bars) at 126-130 or 134-136 days of gestation. There was a significant decrease in IGF-II mRNA/18S rRNA after hypoxemia in fetuses at 134-136 days of gestation. Values are mean \pm S.E.M. ${ }^{\star} P<0 \cdot 05$.
Previous studies have shown that there is a triphasic pattern of cortisol output by the adrenal gland of fetal sheep over the course of gestation (Wintour et al. 1975). Adrenal responsiveness to ACTH is higher in early (day 50-60) and late pregnancy, but essentially absent at 80-120 days. This pattern of ontogenic change reflects, in part, levels of mRNA, immunoreactive protein and enzyme activity for $\mathrm{P} 450_{\mathrm{scc}}$ and $\mathrm{P}_{450} 0_{\mathrm{C} 17}$ in the fetal adrenal cortex (Durand et al. 1984, Tangalakis et al. 1989). $\mathrm{P}^{4} 0_{\mathrm{C} 21}$ mRNA rises gradually throughout pregnancy (Tangalakis et al. 1989), and ir-3 $\beta-H S D$ is present from at least days $50-55$ of gestation. In intact fetuses, 3 $3-\mathrm{HSD}$ activity increases progressively towards term (Manchester et al. 1983). A similar pattern of expression for adrenal steroidogenic enzymes during pregnancy has been reported for bovine fetal adrenal tissue (Conley et al. 1992).

In the fetal sheep adrenal, pregnenolone can be metabolized by either $3 \beta-\mathrm{HSD}$ or $\mathrm{P}^{4} 0_{\mathrm{C} 17}$ pathways in competing reactions. Conley \& Bird (1997) have reviewed information showing that in this species metabolism through the $\Delta 4$ pathway to $17 \alpha$-hydroxyprogesterone $(17 \alpha \mathrm{OH}-\mathrm{P} 4)$ leads to cortisol production, since 
$17 \alpha \mathrm{OH}-\mathrm{P} 4$ is a relatively poor substrate for the C17-20 lyase activity of $\mathrm{P}_{450} \mathrm{C} 17_{7}$. Androstenedione synthesis results from metabolism of pregnenolone through the $\Delta 5$ pathway to DHEA, and then by conversion through $3 \beta-H S D$ activity. Hypoxemia may result in greater attenuation of the $\Delta 5$ pathway to DHEA, limiting formation of adrostenedione, and favoring formation of cortisol from $17 \alpha \mathrm{OH}-\mathrm{P} 4$. In addition, we found a greater increase in $3 \beta-H S D$ than in $\mathrm{P}^{4} 50_{\mathrm{C} 17}$ mRNA, which would favor conversion of pregnenolone through the $\Delta 4$ pathway to cortisol (since the $\Delta 4$ lyase activity is deficient).

It is well documented that ACTH is the major stimulus for acute and chronic phases of adrenal steroidogenesis in vivo and in vitro (Simpson \& Waterman 1988). In fetal sheep, ACTH treatment in vivo increases key enzyme activities, including $\mathrm{P}^{4} 50_{\mathrm{C} 17}$ and $3 \beta-\mathrm{HSD}$ (Naville et al. 1991), and for $\mathrm{P}^{4} 50_{\mathrm{C} 17}$ and $\mathrm{P} 450_{\mathrm{scc}}$ mRNA levels (Tangalakis et al. 1990, 1994). In studies conducted at day 100 of pregnancy, the mRNA levels returned to basal values if the ACTH infusion was stopped for 3 days (Tangalakis et al. 1990, 1992), perhaps reflecting loss of labile ACTH-dependent transcription factor(s). In the present experiments some immaturity of the fetal adrenal response still appears to persist, up to 130 days of gestation, compared with the fetuses studied after that time.

It was surprising that the $\mathrm{P} 450_{\mathrm{C} 17}$ mRNA levels did not increase significantly, and appeared to be less responsive than the 3B-HSD mRNA levels to the effect of $48 \mathrm{~h}$ hypoxemia. Previous in vitro studies have indicated that the $\mathrm{P} 40_{\mathrm{C} 17}$ gene appears to be more sensitive to regulation by ACTH and other trophic agents than $3 \beta-H S D$ (Naville et al. 1991, Cheng et al. 1992, Bird et al. 1996). It is likely that, during hypoxemia, the adrenal response is influenced by the decreased pulsatility of ACTH secretion or by factors other than ACTH. It is known that continuous infusion of ACTH to the ovine fetus leads to greater output of C21 steroids lacking $17 \alpha$ hydroxylation than after pulsatile ACTH (Lye et al. 1983). The pattern of stimulated ACTH output with hypoxemia may more closely reflect continuous output. It is also possible that the adrenal response to ACTH during hypoxemia is attenuated by factors such as transforming growth factor $\beta$ or angiotensin II, and that $\mathrm{P}^{4} 50_{\mathrm{C} 17}$ is affected more than $3 \beta-\mathrm{HSD}$ (Naville et al. 1991). Prostaglandin $\mathrm{E}_{2}\left(\mathrm{PGE}_{2}\right)$ alters levels of $\mathrm{P}^{4} 0_{\mathrm{C} 17}$ and $3 \beta-H S D$ protein and mRNA in bovine adrenal tissue (Rainey et al. 1991), and $\mathrm{PGE}_{2}$, likely of placental origin, increases in fetal sheep plasma in some models of prolonged hypoxemia (Hooper et al. 1990, Murotsuki et al. 1995). The role of $\mathrm{PGE}_{2}$ in the present experiments is not known, and its possible interactions with other agents acting on the adrenal remain to be explored.

In contrast to the effects on steroidogenic enzymes, IGF-II mRNA levels decreased in adrenal tissue after hypoxemia in both groups of animals, although responses were significant only in the older fetuses. Previously, we have shown co-localization of IGF-II mRNA in $3 \beta-H S D$ immunoreactive cells in the ovine fetal adrenal gland indicating that steroidogenic cells are the source of local IGF-II biosynthesis (Han et al. 1992). IGF-II may potentiate mitogenic actions of other growth factors on fetal adrenal growth (Naiman et al. 1989, Mesiano et al. 1993). In culture, IGFs increase ACTH receptor number, steroidogenic activities and steroid and cAMP responses to ACTH (Naiman et al. 1989, Penhoat et al. 1989, Mesiano et al. 1993). The present results are consistent with in vivo studies in fetal sheep showing that infusion of ACTH or cortisol decreases levels of IGF-II mRNA and ir-IGF-II in the adrenal cortex (Lu et al. 1994). Furthermore, when fetal sheep are stressed by fasting in late gestation, there is an increase in plasma cortisol concentration, and a decrease in IGF-II mRNA levels in the fetal liver and kidney ( $\mathrm{Li}$ et al. 1993). Exogenous cortisol infusion reproduces the decline in tissue IGF-II mRNA levels, whereas adrenalectomy prevents the prepartum fall of hepatic IGF-II seen in intact animals (Li et al. 1993).

We speculate that changes in IGF-II gene expression occurring in response to the endocrine events of hypoxemia may have important consequences for the fetus. It is possible that the stress-induced rises in cortisol during hypoxemia attenuate IGF-II gene expression in various other fetal tissues ( $\mathrm{Li}$ et al. 1993). Such a change, if substantiated, may contribute to long-term decreases in tissue weights. In the adrenal gland, prolonged hypoxemia appears to result in diminished responsiveness to ACTH stimulation (Harvey et al. 1993, Murotsuki et al. 1996), but there is an increase in the size of the gland (Murotsuki et al. 1996), accompanied by increased blood flow (Gagnon et al. 1997). We suggest that adrenal cortical hypertrophy may occur as a result of drive from small increments of ir-ACTH and bioactive ACTH in the fetal circulation. ACTH increases cortisol, which decreases IGF-II gene expression, potentially reducing the effects of IGF on the ACTH receptor, cAMP and steroidogenic responses (Naiman et al. 1989, Penhoat et al. 1989, Mesiano et al. 1993). Adrenal cortisol output can be increased by other factors such as $\mathrm{PGE}_{2}$ (Thorburn \& Rice 1990), released in response to hypoxemia (Hooper et al. 1990, Murotsuki et al. 1995). We speculate that this may result in further downregulation of adrenal responsiveness to acute changes in ACTH. The resulting increase in cortisol biosynthesis of the adrenal may shift the metabolic energy of the steroidogenic cells to this important response to stress, away from the IGF-II biosynthesis which is required for tissue growth.

\section{References}

Akagi K \& Challis JRG 1990 Threshold of hormonal and biophysical response to acute hypoxemia in fetal sheep at different gestational ages. Canadian Journal of Physiology and Pharmacology 68 549-555. 
Albrecht ED \& Pepe GJ 1990 Placental steroid hormone biosynthesis in primate pregnancy. Endocrine Reviews 11 124-150.

Auffray C \& Rougeon F 1980 Purification of mouse immunoglobulin heavy-chain messenger RNAs from total myeloma tumor RNA. European Journal of Biochemistry 107 303-314.

Berdusco ETM, Hammond GL, Jacobs RA, Grolla A, Akaji K, Langlois D \& Challis JRG 1993 Glucocorticoid-induced increase in plasma corticosteroid-binding globulin levels in fetal sheep is associated with increased biosynthesis and alterations in glycosylation. Endocrinology 132 2001-2008.

Bird IM, Pasquarette MM, Rainey WE \& Mason IR 1996 Differential control of $17 \alpha$-hydroxylase and $3 \beta$-hydroxysteroid dehydrogenase expression in human adrenocortical H295R cells. Journal of Clinical Endocrinology and Metabolism 81 2171-2178.

Boddy K, Jones CT, Mantell C, Ratcliffe JG \& Robinson JS 1974 Changes in plasma ACTH and corticosteroid of the maternal and fetal sheep during hypoxia. Endocrinology 94 588-591.

Braems GA, Matthews SG \& Challis JRG 1996 Differential regulation of proopiomelanocortin messenger ribonucleic acid in the pars distalis and pars intermedia of the pituitary gland after prolonged hypoxemia in fetal sheep. Endocrinology 137 2731-2738.

Cheng CY, Fiasch MV \& Hornsby PJ 1992 Expression of $17 \alpha$-hydroxylase and $3 \beta$-hydroxysteroid dehydrogenase in human fetal adrenocortical cells transfected with SV40 T antigen. Journal of Molecular Endocrinology 9 7-17.

Conley AJ \& Bird IM 1997 The role of cytochrome P450 $17 \alpha$-hydroxylase and $3 \beta$-hydroxysteroid dehydrogenase in the integration of gonadal and adrenal steroidogenesis via the $\Delta 5$ and $\Delta 4$ pathways of steroidogenesis in mammals. Biology of Reproduction 56 789-799.

Conley AJ, Head JR, Stirling DT \& Mason JI 1992 Expression of steroidogenic enzymes in the bovine placenta and fetal adrenal glands throughout gestation. Endocrinology 130 2641-2650.

Crawford RJ, Hammond VE, Connell JM \& Coghlan JP 1992 The structure and activity of two cytochrome P450 C21 proteins encoded in the ovine adrenal cortex. Journal of Biological Chemistry 267 16212-16218.

Durand P, Cathiard A-M \& Saez JM 1984 In vitro maturation of steroidogenic capacity of ovine fetal and neonatal adrenal cells. Endocrinology 114 1128-1134.

Gagnon R, Murotsuki J, Challis JRG, Fraher L \& Richardson BS 1997 Fetal sheep endocrine responses to sustained hypoxemic stress after chronic fetal placental embolisation. American Journal of Physiology 272 E817-E823.

Han VKM, Lu F, Basssett N, Yang K, Delhanty PJD \& Challis JRG 1992 Insulin-like growth factor-II messenger ribonucleic acid is expressed in steroidogenic cells of the developing ovine adrenal gland is evidence for an autocrine/paracrine role for IGF-II. Endocrinology 131 3100-3109.

Harvey LM, Gilbert RD, Longo LD \& Ducsay CA 1993 Changes in ovine fetal adrenocortical responsiveness after long-term hypoxemia. American Journal of Physiology 264 E741-E747.

Hooper SB, Coulter CL, Deayton JM, Harding R \& Thorburn GD 1990 Fetal endocrine responses to prolonged hypoxemia in sheep. American Journal of Physiology 259 R703-R708.

Li J, Saunders JC, Gilmour RS, Silva M \& Fowden AL 1993 Insulin-like growth factor-II messenger ribonucleic acid expression in fetal tissues of sheep during late gestation: effects of cortisol. Endocrinology 132 2083-2089.

Liggins GC 1994 The role of cortisol in preparing the fetus for birth. Reproduction Fertility and Development 6 141-150.

Lorrence MC, Murray BA, Trant JM \& Mason JI 1990 Human 3 beta-hydroxysteroid dehydrogenase/delta 5-delta 4 isomerase from human placenta: expression in non-steroidogenic cells of the protein that catalyses dehydrogenation/isomerisation of C21 and C19 steroids. Endocrinology 126 2493-2498.

Lu F, Han VKM, Milne WK, Fraser M, Carter AM, Berdusco ETM \& Challis JRG 1994 Regulation of insulin-like growth factor-II gene expression in the ovine fetal adrenal gland by adrenocorticotropic hormone and cortisol. Endocrinology 134 2628-2635.

Lye SJ, Sprague CL, Mitchell BF \& Challis JRG 1983 Activation of ovine fetal adrenal functions by pulsatile or continuous administration of adrenocorticotropin-(1-24): effects on fetal plasma corticosteroids. Endocrinology 113 770-782.

Manchester EL, Lye SJ \& Challis JRG 1983 Activation of ovine fetal adrenal function by pulsatile or continuous administration of adrenocorticotropin-(1-24): effects on adrenal cell responses in vitro. Endocrinology 113 777-782.

Mason JI, Ushijima K, Doody KM, Wagai K, Naville D, Head JR, Milewich L, Rainey WW \& Ralph MM 1993 Regulation of expression of the $3 \beta$-hydroxysteroid dehydrogenases of human placenta and fetal adrenal. Journal of Steroid Biochemistry and Molecular Biology 47 1-6.

Matthews SG \& Challis JRG 1996 Regulation of the hypothalamopituitary-adrenal axis in fetal sheep. Trends in Endocrinology and Metabolism 7 239-246.

Mesiano S, Mellon SH \& Jaffe RB 1993 Mitogenic action, regulation and localization of insulin-like growth factors in the human fetal adrenal gland. Journal of Clinical Endocrinology and Metabolism 76 968-976.

Mitchell BF, Lye SJ, Lukash L \& Challis JRG 1986 Androstenedione metabolism in the late gestation sheep fetus. Endocrinology 118 63-68.

Murotsuki J, Challis JRG, Johnston L \& Gagnon R 1995 Increased fetal plasma prostaglandin $\mathrm{E}_{2}$ concentrations during fetal placental embolization in pregnant sheep. American Journal of Obstetrics and Gynecology 173 30-35.

Murotsuki J, Gagnon R, Matthews SG \& Challis JRG 1996 Effects of long-term hypoxemia on pituitary-adrenal function in sheep. American Journal of Physiology 271 E678-E685.

Naiman E, Chatelain P, Saez JM \& Durand P 1989 In vitro effect of insulin and insulin-like growth factor-I on cell multiplication and adrenocorticotropin responsiveness of fetal adrenal cells. Biology of Reproduction 40 570-577.

Naville D, Rainey WE \& Mason JI 1991 Corticotropin regulation of $3 \beta$-hydroxysteroid dehydrogenase $/ \Delta^{5}-\Delta^{4}$ isomerase in ovine adrenocortical cells; inhibition by transforming growth factor $\beta$. Molecular and Cellular Endocrinology 75 257-263.

Norman LJ, Lye SJ, Wlodek ME \& Challis JRG 1985 Changes in pituitary responses to synthetic ovine corticotropin-releasing factor in fetal sheep. Canadian Journal of Physiology and Pharmacology 63 1398-1403.

Penhoat A, Jailard C \& Saez JM 1989 Synergistic effects of corticotropin and insulin-like growth factor-I on corticotropin receptors and corticotropin responsiveness in cultural bovine adrenocortical cells. Biochemical and Biophysical Research Communications 165 355-359.

Pepe GJ \& Albrecht ED 1990 Regulation of primate fetal adrenal cortex. Endocrine Reviews 11 151-176.

Phillips ID, Ross JT, Owens JA, Young IR \& McMillen IR 1996 The peptide ACTH(1-39), adrenal growth and steroidogenesis in the sheep fetus after disconnection of the hypothalamus and pituitary. Journal of Physiology 491 871-879.

Rainey WE, Naville D, Cline N \& Mason JI 1991 Prostaglandin $E_{2}$ is a positive regulator of adrenocorticotropin receptors, $3 \beta$-hydroxysteroid dehydrogenase, and $17 \alpha$-hydroxylase expression in bovine adrenocortical cells. Endocrinology 129 1333-1339.

Reinisch JM, Simon NG, Karow WG \& Gandman R 1978 Prenatal exposure to prednisone in humans and animals retards intrauterine growth. Science 202 436-438.

Riley SC, Boshier DP, Luu-Thé V, Labrie F \& Challis JRG 1992 Immunohistochemical localisation of $3 \beta$-hydroxysteroid dehydrogenase $/ \Delta^{5}-\Delta^{4}$ isomerase, tyrosine hydroxylase and phenylethanolamine $\mathrm{N}$-methyl transferase in the adrenal glands of sheep fetuses throughout gestation and in neonates. Journal of Reproduction and Fertility 96 127-134. 
Rurak DW 1978 Plasma vasopressin levels during hypoxaemia and the cardiovascular effects of exogenous vasopressin in foetal and adult sheep. Journal of Physiology 277 341-357.

Sambrook J, Fritsch F \& Maniatis T 1989 Molecular Cloning, edn 2. Cold Spring Harbor, New York: Laboratory Press.

Seron-Ferre M, Lawrence C, Siiteri PK \& Jaffe RB 1978 Steroid production by definitive and fetal zones of the human fetal adrenal gland. Journal of Clinical Endocrinology and Metabolism 47 603-609.

Simpson ER \& Waterman MR 1988 Regulation of the synthesis of steroidogenic enzymes in adrenal cortical cells by ACTH. Annual Review of Physiology $\mathbf{5 0}$ 427-440.

Stark RI, Wardlaw SL, Daniel SS, Hussain MK, Sanocka UM, James LS \& van de Wiele RL 1982 Vasopressin secretion induced by hypoxia in sheep: developmental changes and the relationship to $\beta$-endorphin release. American Journal of Obstetrics and Gynecology 143 204-215.

Tangalakis K, Coghlan JP, Connell J, Crawford R, Darling P, Hammond VE, Haralambidis J, Penschow J \& Wintour EM 1989 Tissue distribution and levels of gene expression of three steroid hydroxylases in ovine adrenal glands. Acta Endocrinologica $\mathbf{1 2 0}$ $225-232$.
Tangalakis K, Coghlan JP, Crawford R, Hammond VE \& Wintour EM 1990 Steroid hydroxylase gene expression in the ovine adrenal gland following ACTH infusion. Acta Endocrinologica 123 371-377.

Tangalakis K, Roberts FE \& Wintour EM 1992 The time-course of ACTH stimulation of cortisol synthesis by the immature ovine foetal adrenal gland. Journal of Steroid Biochemistry and Molecular Biology 42 527-532.

Tangalakis K, Crawford R, McFarlane AC \& Wintour WM 1994 Regulation of steroid hydroxylase gene expression in the ovine fetal adrenal at 0.4 gestation. Molecular and Cellular Endocrinology 103 21-27.

Thorburn GD \& Rice GE 1990 Placental $\mathrm{PGE}_{2}$ and the initiation of parturition in the sheep. In Eicosanoids in Reproduction, pp 73-86. Ed. MD Mitchell. Boca Raton, FL: CRC Press.

Wintour EM, Brown EH, Denton DA, Hardy KJ, McDougall JG, Oddie CJ \& Whipp GT 1975 The ontogeny and regulation of corticosteroid secretion by the ovine fetal adrenal. Acta Endocrinologica 79 301-316.

Received 18 March 1998

Accepted 30 June 1998 